\title{
Assessment of sulfamethoxazole adsorption capacity on Pirangi clay from the State of Sergipe, Brazil, modified by heating and addition of organic cation
}

\author{
(Avaliação da capacidade de adsorção de sulfametoxazol \\ em argila Pirangi do estado de Sergipe, Brasil, modificada \\ por aquecimento e adição de cátion orgânico)
}

\author{
J.C.T. de Rezende ${ }^{1}$, V.H.S. Ramos ${ }^{1}$, A.S.Silva ${ }^{2}$, C.P.Santos ${ }^{3}$, H.A. Oliveira ${ }^{4}$, E. de Jesus ${ }^{1 *}$ \\ ${ }^{1}$ Universidade Federal de Sergipe, Department of Chemical Engineering, Av. Marechal Rondon, \\ $s / n, 49100-000$, S. Cristóvão, SE, Brazil \\ ${ }^{2}$ Universidade Federal de Sergipe, Department of Mathematics, S. Cristóvão, SE, Brazil \\ ${ }^{3}$ Universidade Federal de Sergipe, Department of Physics, S. Cristóvão, SE, Brazil \\ ${ }^{4}$ Federal Institute of Sergipe, Estância, SE, Brazil
}

\begin{abstract}
Sulfamethoxazole (SMX) is a widely-used antibiotic in human and veterinary medicine for treating diseases and infections and is often detected in the surface water ecosystem. Thus, this study evaluated the capacity of removing SMX from aqueous systems using Pirangi clay (PIR) from the state of Sergipe (Brazil). Pirangi clay samples were treated at 100,400 and $600{ }^{\circ} \mathrm{C}$ and modified with hexadecyltrimethylammonium (HDTMA) cationic surfactant. The modification process used was based on the layered organization of the mineral clay, allowing the intercalation of cationic surfactant, giving a hydrophobic character to the clay. The Pirangi clay treated at $100{ }^{\circ} \mathrm{C}$ and modified with HDTMA (org-PIR-100) showed adsorption capacity of 27.3 mg.g ${ }^{-1}$ with $90 \%$ removal of the SMX in $100 \mathrm{~min}$ and $\mathrm{pH}$ 6, following the pseudo-second-order model and Langmuir isotherm. Different characterization methods were employed to characterize the clays, such as XRF, FTIR, XRD, thermogravimetric analyzes (TG/DTG) and BET method, confirming that the surfactant molecules were incorporated on the clay surface and that org-PIR-100 showed potential for use in water treatment plant filters.
\end{abstract}

Keywords: Pirangi clay, organoclay, adsorption, sulfamethoxazole.

Resumo

O sulfametoxazol (SMX) é um antibiótico amplamente usado no tratamento de doenças e infecções é é frequentemente detectado em ecossistema de águas superficiais. Assim, este trabalho avaliou a capacidade de remoção deste antibiótico de sistemas aquosos utilizando argila Pirangi (PIR) do estado de Sergipe (Brasil). Amostras de argila Pirangi foram tratadas termicamente a 100, 400 e $600{ }^{\circ} \mathrm{C}$ e posteriormente modificadas com surfactante cationico HDTMA. A modificação realizada baseou-se na organização em camadas da argila mineral possibilitando intercalação de surfactante catiônico, atribuindo caráter hidrofóbico à argila. A argila Pirangi tratada termicamente a $100^{\circ} \mathrm{C}$ organofilica (org-PIR-100) apresentou maior capacidade máxima de adsorção de 27,3 mg. $\mathrm{g}^{-1}$ com remoção de 90\% do SMX em 100 min e pH 6, seguindo o modelo de pseudossegunda ordem e isoterma de Langmuir. As argilas foram caracterizadas por FRX, FTIR, DRX, TG/DTG e BET, confirmando que as moléculas do surfactante foram incorporadas na superficie da argila e que a org-PIR-100 apresentou potencial para o uso em filtros de estações de tratamento de água.

Palavras-chave: argila Pirangi, argila organofílica, adsorção, sulfametoxazol.

\section{INTRODUCTION}

The detection of organic micropollutants in aquatic environments has received attention from researchers in several countries [1]. Within this group of contaminants, mention should be made of pharmaceuticals, personal

*edilsonjs@ufs.br

Dhttps://orcid.org/0000-0003-4239-6050 care products, hormones and steroids which present a threat to human health and the environment, even at low concentrations ( $\mu \mathrm{g} . \mathrm{L}^{-1}$ and $\left.\mathrm{ng} . \mathrm{L}^{-1}\right)$, and which may have effects on endocrine disruption, resistance to chemical, photolytic and biological degradation, high bioaccumulation potential and long-range transport and distribution through the atmosphere and water bodies [2, 3]. In addition, the contaminants are not regulated or are subject to the extension process $[3,4]$. Sulfamethoxazole or 4-amino-N- 
(5-methyl-1,2-oxazol-3-yl) benzenesulfonamide (SMX) is an antibiotic belonging to the sulfonamide group and is considered as one of the representatives of the group with higher concentrations in the environment due to its ample prescription and consumption for human and veterinary treatments of diseases and infections, mainly urinary infections [5-7].

Several methods can be used to remove micropollutants from contaminated water. Adsorption has been considered an effective method to complement existing water and sewage treatment systems with the aim to improve the removal of organic pollutants $[8,9]$, and is widely used due to its efficiency, simplicity, ease of projection and execution, faster removal of pollutants and low cost [10-12]. In the physicalchemical treatment of water for human consumption, granular materials such as clay and activated carbon are used in the filters of water treatment plants as adsorbents of organic micropollutants. Among the various granular materials which can compose the filter media, it is possible to highlight clays which have received attention for being natural adsorbents, as well as for their ion exchange properties, profitability, lowcost and wide availability $[9,13]$. Sergipe is a State in the northeastern region of Brazil which has an industrial park manufacturing structural and ceramic artifacts. It has several clay mines located in the municipalities of Itabaiana, Nossa Senhora do Socorro, Siriri, Cedro de São João, Laranjeiras, Santana of São Francisco and Simão Dias. Due to this production, clay studies are concentrated in structural and tile ceramics, but studies in the area of adsorption of organic compounds are still poorly investigated or reported [14-18].

Organophilic clays are modified forms of clay minerals in which the exchange of inorganic cations by ions of quaternary ammonium salts occurs on the outer surface or in the interlamellar clay spacing, modifying the chemical nature of hydrophilic to hydrophobic, favoring adsorption of organic compounds [19]. This modification is based on the layered organization of the mineral clay, allowing the intercalation of cationic surfactant (organic cation), giving a hydrophobic character to the clay; the structure and composition of the clay minerals can be altered by heating before adding the organic cation in the clay, causing loss of surface water, constitution water and changes in clay properties due to thermochemical reactions $[20,21]$. The objectives in this study were to analyze the adsorption capacity of Pirangi clay from the State of Sergipe (Brazil) in its natural, thermally treated and organophilic forms obtained by the modification process with quaternary ammonium salt (HDTMA) and to evaluate the structural properties of these clays through of XRF, FTIR, XRD, TG/DTG and BET analyses. In addition, the adsorption behavior of SMX in organophilic clay (org-PIR-100) was evaluated through the influence of $\mathrm{pH}$, kinetics, equilibrium isotherms and thermodynamic variables.

\section{MATERIALS AND METHODS}

Clay sampling: the raw Pirangi clay sample was collected from a mine of the São José Ceramic Co. located in the Itabaianinha municipality in the State of Sergipe-Brazil. Thermal treatment of clay: $300 \mathrm{~g}$ sample of Pirangi raw clay (PIR) was sampled by quartering and oven-dried (Sterilifer) at $40 \pm 10{ }^{\circ} \mathrm{C}$ for $48 \mathrm{~h}$ and then granulometric reduction was performed by a hammer mill (Servitech, CT 12061). Samples of $90 \mathrm{~g}$ of raw clay (35-100 mesh) were heat-treated at $100{ }^{\circ} \mathrm{C}$ (PIR-100), $400{ }^{\circ} \mathrm{C}$ (PIR-400) and $600{ }^{\circ} \mathrm{C}$ (PIR-600) in a muffle furnace (GP Científica) for $24 \mathrm{~h}$.

Preparation of organo-Pirangi: samples of $15 \mathrm{~g}$ of PIR raw clay and $15 \mathrm{~g}$ of each thermally treated clay (PIR-100, PIR-400, and PIR-600) with 35-100 mesh granulometry were used. Each clay sample was gradually added in $250 \mathrm{~mL}$ of distilled water contained in beakers under constant mechanical stirring, then sodium carbonate (Reagen, P.A.) was added to each dispersion following the ratio of $10 \mathrm{meq} / 100 \mathrm{~g}$ dry clay, maintaining constant stirring for $24 \mathrm{~h}$ at room temperature $\left(25 \pm 1{ }^{\circ} \mathrm{C}\right)$, and the dispersions were then heated at $80 \pm 10{ }^{\circ} \mathrm{C}$ for $30 \mathrm{~min}$. After the cation exchange procedure, $4.50 \mathrm{~g}$ of ammonium hexadecyltrimethylammonium bromide - HDTMA (purity $\geq 99 \%$, Sigma-Aldrich) equivalent to $30 \mathrm{~g}$ of HDTMA $/ 100 \mathrm{~g}$ dry clay was gradually added and the stirring was continued for $20 \mathrm{~min}$ after addition. The dispersions were subsequently separated using a centrifuge (MLW, Janetzki T23) and then washed successively with distilled water. After these steps, the obtained samples were oven-dried at $60 \pm 10{ }^{\circ} \mathrm{C}$ for $48 \mathrm{~h}$, disaggregated using mortar and pestle and screened in a 100 mesh $(0.15 \mathrm{~mm})$ sieve. This procedure was performed based on the methodology described in [22]. After modification, the organophilic clays were named org-PIR, org-PIR-100, org-PIR-400 and org-PIR-600.

Characterization of clays: the organic matter content was determined by the ignition method described by the ASTM D2974-00 standard [23]. The loss on ignition was evaluated from the weight difference between samples heated at 100 and $1000{ }^{\circ} \mathrm{C}$ for $2 \mathrm{~h}$ [24]. Cation exchange capacity (CEC) was determined by the methylene blue method according to ASTM C837-09 [25]. The point of zero charge $\left(\mathrm{pH}_{\mathrm{PZC}}\right)$ was determined following the methodology described in [26]. The constituent oxide percentages of the clays were determined by X-ray fluorescence (XRF) spectrometry (standardless analysis) using a Bruker S8Tiger. Fourier-transform infrared (FTIR) spectra of the samples were measured on a Varian 640-IR spectrometer in the form of $\mathrm{KBr}$-pressed pellet in the region of 4000 to $400 \mathrm{~cm}^{-1}$. The crystalline structures and basal spacing of the materials were identified using X-ray diffractometry (XRD) on a Bruker D8 Advance with $\mathrm{CuK} \alpha$ radiation, $40 \mathrm{kV}$ voltage, $40 \mathrm{~mA}$ current, $2^{\circ}$ to $60^{\circ}$ angle, with scanning speed of $1^{\circ} \cdot \mathrm{min}^{-1}$, step size of $0.02^{\circ}$ and time per step of $0.2 \mathrm{~s}$. The $\mathrm{d}_{001}$ spacings of the materials were determined by the first reflection of (001) and calculated by the Bragg law $(\mathrm{n} . \lambda=2 . \mathrm{d} \cdot \sin \theta)$, where $\mathrm{n}$ is an integer wavelength $(\mathrm{n}=1), \lambda$ is the wavelength of the incident radiation $(\lambda=1.5418 \AA)$, $\mathrm{d}$ is the interplanar spacing and $\theta$ is the incident angle of the radiation. The thermal analyses were performed in simultaneous thermogravimetry (TG/DTG) equipment 
(Netzsch, STA 449 F1 Jupiter) in the range of 25 to $1200{ }^{\circ} \mathrm{C}$, with a heating rate of $10{ }^{\circ} \mathrm{C} \cdot \mathrm{min}^{-1}$ under $\mathrm{N}_{2}$ atmosphere at a flow rate of $100 \mathrm{~mL} \cdot \mathrm{min}^{-1}$. The specific surface area, total pore volume and pore size of Brunauer-Emmett-Teller (BET) were obtained by adsorption-desorption isotherm of $\mathrm{N}_{2}$ at $77 \mathrm{~K}$ using a Micromeritics ASAP 2020 analyzer. Samples were initially subjected to vacuum degassing at $100{ }^{\circ} \mathrm{C}$ for $2 \mathrm{~h}$.

Preparation of standard SMX solution: the tests were performed using sulfamethoxazole (SMX) analytical standard from Sigma-Aldrich. The standard working solutions were prepared using Milli-Q ultra-pure water (Gehaka, Master System MS2000) from dilutions of the $100 \mathrm{mg} . \mathrm{L}^{-1}$ antibiotic stock solution, initially solubilized in $1 \mathrm{~mL}$ of methanol (Honeywell, HPLC grade). Batch adsorption tests of SMX: $0.1 \mathrm{~g}$ of adsorbent was added to Erlenmeyer flasks containing $50 \mathrm{~mL}$ of the SMX adsorbate at specified concentrations. The $\mathrm{pH}$ of the solution was adjusted to the working range using $\mathrm{HCl}$ (Impex, P.A.) and $\mathrm{NaOH}$ (Alphatec, P.A.), both at $0.1 \mathrm{~mol}^{-\mathrm{L}^{-1}}$. The flasks were shaken in an orbital shaker (M.S.S MSM, 130/PGA/F) at $150 \mathrm{rpm}$. After adsorption, the samples were filtered on a $0.22 \mu \mathrm{m}$ nylon membrane filters (Unichro) and then the SMX concentration was analyzed using a Shimadzu 20A Ultra Fast Liquid Chromatography equipped with a precolumn (Sigma-Aldrich, C18; 250x4.6 mm, $5 \mu \mathrm{m}$ ) and UVvis diode array detector (UFLC-DAD). The analyses were performed based on the method and conditions established in [27], using isocratic elution, mobile phase acetonitrile (AppliChem, UHPLC grade) and Milli-Q water (50:50 v/v), mobile phase flow of $1.0 \mathrm{~mL} \cdot \mathrm{min}^{-1}$, injection volume of $20 \mu \mathrm{L}$, wavelength for detection of $268 \mathrm{~nm}$ and retention time around $4 \mathrm{~min}$. The batch adsorption tests were performed in triplicate. The amount of SMX adsorbed at equilibrium, $\mathrm{Q}_{\mathrm{e}}\left(\mathrm{mg} \cdot \mathrm{g}^{-1}\right)$, and the removal percentage, $\mathrm{R} \%$, were calculated by:

$$
\begin{aligned}
& \mathrm{Q}_{\mathrm{e}}=\frac{\left(\mathrm{C}_{0}-\mathrm{C}_{\mathrm{e}}\right) \cdot \mathrm{V}}{\mathrm{m}} \\
& \mathrm{R} \%=\frac{\mathrm{C}_{0}-\mathrm{C}_{\mathrm{f}}}{\mathrm{C}_{0}} \cdot 100
\end{aligned}
$$

where $\mathrm{C}_{0}, \mathrm{C}_{\mathrm{e}}$, and $\mathrm{C}_{\mathrm{f}}$ are the initial, equilibrium and final concentrations of SMX in the solution, respectively, $\mathrm{V}$ is the solution volume $(\mathrm{L})$ and $\mathrm{m}$ is the adsorbent mass $(\mathrm{g})$. Influence of $p H$ : this influence on the SMX adsorption was evaluated at $\mathrm{pH} 2,4,6,8$ and 10, with initial concentration of adsorbate equal to $10 \mathrm{mg} . \mathrm{L}^{-1}$, at room temperature $\left(25^{\circ} \mathrm{C}\right)$ for $120 \mathrm{~min}$ according to batch method.

Adsorption kinetics: the adsorption kinetics of SMX were studied at the initial adsorbate concentration of 10 $\mathrm{mg} . \mathrm{L}^{-1}$ at room temperature $\left(25^{\circ} \mathrm{C}\right)$, using the previously determined optimum $\mathrm{pH}$ in the time range between 2 and $180 \mathrm{~min}$ and using the batch method. The pseudo-firstorder model (Eq. C) and pseudo-second-order (Eq. D) were used in estimating the kinetic parameters:

$$
\begin{aligned}
& Q_{t}=Q_{e} \cdot\left(1-\exp ^{-k_{1} t}\right) \\
& Q_{t}=\frac{Q_{e}^{2} \cdot k_{2} \cdot t}{1+Q_{e} \cdot k_{2} \cdot t}
\end{aligned}
$$

where $t$ represents the contact time between adsorbent and adsorbate $(\mathrm{min}), \mathrm{Q}_{\mathrm{t}}$ is the amount of the adsorbed SMX per unit mass at time $t\left(\mathrm{mg} \cdot \mathrm{g}^{-1}\right), \mathrm{Q}_{\mathrm{e}}$ is the amount of SMX adsorbed when equilibrium is reached $\left(\mathrm{mg} \cdot \mathrm{g}^{-1}\right), \mathrm{k}_{1}$ is the constant rate of pseudo-first-order $\left(\mathrm{min}^{-1}\right)$ and $\mathrm{k}_{2}$ is the constant rate of pseudo-second-order $\left(\mathrm{g} \cdot \mathrm{mg}^{-1} \cdot \mathrm{min}^{-1}\right)$.

Adsorption equilibrium and thermodynamics: the data for constructing the isotherms were obtained by varying the initial SMX concentration between 5 and $60 \mathrm{mg} . \mathrm{L}^{-1}$ at the previously determined optimum $\mathrm{pH}$, stirring time of $3 \mathrm{~h}$, and at different temperatures $\left(15,25,35\right.$ and $\left.45^{\circ} \mathrm{C}\right)$ using the batch method. The Langmuir (Eq. E) and Freundlich (Eq. F) models were used in this study:

$$
\begin{aligned}
& Q_{e}=\frac{Q_{\max } \cdot b \cdot C_{e}}{1+b \cdot C_{e}} \\
& Q_{e}=K_{f} \cdot C_{e}^{1 / n}
\end{aligned}
$$

where $\mathrm{Q}_{\max }$ is the maximum adsorption capacity of Langmuir $\left(\mathrm{mg} \cdot \mathrm{g}^{-1}\right), \mathrm{b}$ is the Langmuir adsorption affinity parameter $\left(\mathrm{L}^{\mathrm{mg}} \mathrm{m}^{-1}\right), \mathrm{C}_{\mathrm{e}}$ is the concentration of SMX at equilibrium $\left(\mathrm{mg} . \mathrm{L}^{-1}\right), \mathrm{K}_{\mathrm{f}}$ is a Freundlich constant related to adsorption capacity $\left[\left(\mathrm{mg} \cdot \mathrm{g}^{-1}\right) \cdot\left(\mathrm{L} \cdot \mathrm{mg}^{-1}\right)^{1 / n}=\left(\mathrm{L} \cdot \mathrm{g}^{-1}\right)^{1 / \mathrm{n}}\right]$ and $1 / \mathrm{n}$ is an empirical constant of the Freundlich model describing the adsorption intensity or surface heterogeneity. The Eq. $G$ represents a dimensionless equilibrium parameter known as the $\mathrm{R}_{\mathrm{L}}$ separation factor that indicates the degree of development of the adsorption process, valid for the Langmuir isotherm [28]:

$$
\mathrm{R}_{\mathrm{L}}=\frac{1}{\left(1+\mathrm{C}_{0} \cdot \mathrm{b}\right)}
$$

where $\mathrm{C}_{0}$ is the highest concentration of SMX in solution $\left(\mathrm{mg} . \mathrm{L}^{-1}\right)$. The thermodynamic parameters [29] can be calculated by:

$$
\begin{aligned}
& \mathrm{K}_{\mathrm{C}}=\frac{\mathrm{Q}_{\mathrm{e}}}{\mathrm{C}_{\mathrm{e}}} \\
& \ln \mathrm{K}_{\mathrm{C}}=\frac{\Delta \mathrm{S}^{\mathrm{o}}}{\mathrm{R}}-\frac{\Delta \mathrm{H}^{\mathrm{o}}}{\mathrm{R} \cdot \mathrm{T}} \\
& \Delta \mathrm{G}^{\mathrm{o}}=\Delta \mathrm{H}^{\mathrm{o}}-\mathrm{T} \cdot \Delta \mathrm{S}^{\mathrm{o}}
\end{aligned}
$$

where $\mathrm{K}_{\mathrm{C}}$ is the adsorbent distribution coefficient $\left(\mathrm{L} \cdot \mathrm{g}^{-1}\right)$, $\mathrm{T}$ represents the absolute temperature $(\mathrm{K})$ and $\mathrm{R}$ is the universal gas constant $\left(8.3145 \mathrm{~J} \cdot \mathrm{mol}^{-1} \cdot \mathrm{K}^{-1}\right)$. The values of $\Delta \mathrm{S}^{\circ}$ and $\Delta \mathrm{H}^{\circ}$ were calculated from the plot of $\operatorname{lnK}_{\mathrm{C}}$ versus $1 / \mathrm{T}$. Estimation of kinetic parameters and adsorption equilibrium: Eq. $\mathrm{K}$ represents the function of least squares (SSE) used in the estimation of kinetic parameters and adsorption equilibrium. The non-linear estimation was performed using Statistica 
10.0 software, using the Levenberg-Marquardt method and a $95 \%$ confidence level $(\alpha=0.05)$.

$$
\mathrm{SSE}=\sum_{\mathrm{i}=1}^{\mathrm{n}}\left(\mathrm{Q}_{\mathrm{e}, \text { alc }}-\mathrm{Q}_{\mathrm{e}, \exp }\right)_{\mathrm{i}}^{2}
$$

where $\mathrm{Q}_{e, \text { exp }}$ is the adsorption capacity at the experimental equilibrium, $\mathrm{Q}_{\mathrm{e}, \mathrm{calc}}$ is the equilibrium adsorption capacity calculated using the isotherm model and $\mathrm{n}$ is the number of experimental data.

\section{RESULTS AND DISCUSSION}

According to Table I, the SMX adsorption experiments were preliminarily performed using $50 \mathrm{~mL}$ of the $10 \mathrm{mg} . \mathrm{L}^{-1}$ adsorbate at $\mathrm{pH} 6,0.1 \mathrm{~g}$ of the in natura, thermally treated and organophilic clays, shaken at $150 \mathrm{rpm}$ for $120 \mathrm{~min}$. The org-PIR-100 clay presented the highest percentage of SMX removal, which was chosen for the other adsorption stages and characterization studies. However, the PIR and PIR100 clays were also studied in the characterizations in order to evaluate possible modifications among the materials. The non-removal of SMX in the in natura and thermally treated clays was due to the nature of the natural clays being generally hydrophilic, resulting in small adsorption capacity of organic contaminants. The surface character of these clays can be modified by ion exchange whose cationic sites can be occupied by surfactants, changing the nature of the hydrophilic to organophilic surface [18].

Table I - SMX removal percentage (R\%) of clays in study. [Tabela I - Porcentagem de remoção de SMX (R\%) das argilas em estudo.]

\begin{tabular}{ccc}
\hline Sample & Nomenclature & $\mathrm{R} \%$ \\
\hline In natura clay & PIR & $0 \%$ \\
\hline \multirow{2}{*}{ Thermally-treated } & PIR-100 & $0 \%$ \\
clays & PIR-400 & $0 \%$ \\
& PIR-600 & $0 \%$ \\
\hline \multirow{4}{*}{ Organophilic clays } & org-PIR & $34.5 \%$ \\
& org-PIR-100 & $89.2 \%$ \\
& org-PIR-400 & $11.2 \%$ \\
& org-PIR-600 & $0 \%$ \\
\hline
\end{tabular}

The CEC values for PIR,PIR-100, and org-PIR-100 were, respectively, 26.9, 14.3 and $3.2 \mathrm{cmol} . \mathrm{kg}^{-1}$. The obtained CEC values were characteristic of illite $\left(9-40 \mathrm{cmol} . \mathrm{kg}^{-1}\right)$ [30]. It was observed that the CEC for the org-PIR-100 was lower than the other clays due to the presence of surfactant, which reduced the cation exchange capacity of the clay [18]. The chemical composition of clays expressed as a percentage of oxides is shown in Table II. The loss on ignition (LOI) of the organic-PIR-100 clay was higher (16.94\%) due to the incorporation of organic cation (Table II). The organic matter content (Table II) determined by ignition was PIR clay $=5.48 \%$, PIR-100 clay $=3.91 \%$, and org-PIR-100 clay $=16.52 \%$. These results showed that the CEC for PIR clay and modified PIR clays was also influenced by the organic matter content, as well as the chemical composition of the clay minerals present in the clay [31]. The chemical analysis showed that all the samples presented $\mathrm{SiO}_{2}$ and $\mathrm{Al}_{2} \mathrm{O}_{3}$ as the predominant oxides. These oxides were associated with the silica tetrahedral sheet and the alumina octahedral sheet, basic units that form the clay structure, and may be associated with kaolinite, illite, and silica from quartz. The $\mathrm{Na}_{2} \mathrm{O}, \mathrm{CaO}, \mathrm{MgO}$, and $\mathrm{K}_{2} \mathrm{O}$ were associated with the exchangeable cations of interlamellar space of the clays, normally $\mathrm{Na}^{+}$and $\mathrm{Ca}^{2+}[14,32]$. In addition, only orgPIR-100 presented $\mathrm{Br}$ from the composition of HDTMA $\left(\mathrm{C}_{19} \mathrm{H}_{42} \mathrm{BrN}\right)$ used in the clay modification.

Table II - Chemical composition, organic matter (OM) content and loss on ignition (LOI) of clays (\%).

[Tabela II - Composição química, teor de matéria orgânica (OM) e perda ao fogo (LOI) das argilas (\%).]

\begin{tabular}{cccc}
\hline Sample & PIR & PIR-100 & org-PIR-100 \\
\hline $\mathrm{SiO}_{2}$ & 63.43 & 63.31 & 67.03 \\
$\mathrm{Al}_{2} \mathrm{O}_{3}$ & 19.03 & 19.25 & 14.43 \\
$\mathrm{Fe}_{2} \mathrm{O}_{3}$ & 6.12 & 5.96 & 4.24 \\
$\mathrm{Na}_{2} \mathrm{O}$ & 3.79 & 4.13 & 5.27 \\
$\mathrm{CaO}$ & 2.82 & 2.73 & 2.83 \\
$\mathrm{MgO}$ & 1.82 & 1.87 & 0.94 \\
$\mathrm{~K}_{2} \mathrm{O}$ & 1.76 & 1.72 & 1.80 \\
$\mathrm{TiO}_{2}$ & 0.79 & 0.72 & 0.46 \\
$\mathrm{BaO}$ & 0.12 & 0.13 & 0.11 \\
$\mathrm{MnO}$ & 0.07 & 0.07 & 0.06 \\
$\mathrm{SrO}$ & 0.06 & 0.06 & 0.06 \\
$\mathrm{ZrO}$ & 0.06 & 0.05 & - \\
$\mathrm{Cr}_{2} \mathrm{O}_{3}$ & 0.03 & - & - \\
$\mathrm{Cl}$ & 0.10 & - & - \\
$\mathrm{Br}$ & - & - & 2.77 \\
$\mathrm{LOI}$ & 6.65 & 5.71 & 16.94 \\
$\mathrm{OM}$ & 5.48 & 3.91 & 16.52 \\
\hline
\end{tabular}

The infrared spectroscopy analyses were carried out in order to analyze the functional groups in the clay structure. Fig. 1 shows the obtained FTIR spectra. The band at 3700 and $3400 \mathrm{~cm}^{-1}$ were characteristic of the stretching vibration of $\mathrm{OH}$ groups. The band at $2365 \mathrm{~cm}^{-1}$ corresponded to atmospheric $\mathrm{CO}_{2}$ [20]. The band at $1635 \mathrm{~cm}^{-1}$ was related to the bending vibration of $-\mathrm{OH}$ of water adsorbed on clay $[22,33,34]$. The band attributed to the Si-O stretching vibration occurred at the 1028 and $770 \mathrm{~cm}^{-1}$ regions [33, 35, 36], while the 531 and $463 \mathrm{~cm}^{-1}$ bands suggested the bending vibration of Al-O-Si and Si-O-Si, respectively [36], which were predominant in the clays as analyzed by the XRF technique. In the organophilic clay spectrum (org-PIR-100), bands were observed at the regions of around 2920 and 
$2850 \mathrm{~cm}^{-1}$, which corresponded to the asymmetric and symmetrical stretching, respectively, of the $\mathrm{CH}_{2}$ groups from the organic chain of the quaternary salt incorporated into the clay. It was observed that there was a decrease in intensity of the $1635 \mathrm{~cm}^{-1}$ band, which was related to the establishment of electrostatic interactions between cationic surfactant and hydroxyl groups of clay [31]. The band appearing at $1470 \mathrm{~cm}^{-1}$ indicated the presence of the $\mathrm{C}-\mathrm{N}$ functional group corresponding to the HDTMA tertiary amine $[19,26]$. Thus, the FTIR spectra confirmed that the surfactant was intercalated in the intermediate layer or adsorbed on the clay surface [29].

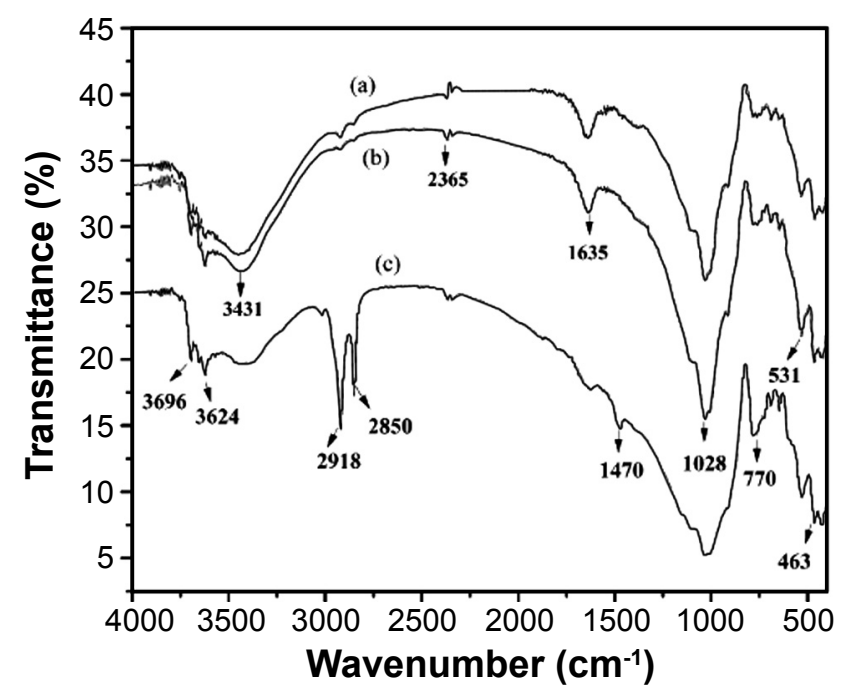

Figure 1: FTIR spectra of clays: a) PIR; b) PIR-100; and c) orgPIR-100.

[Figura 1: Espectros de FTIR das argilas: a) PIR; b) PIR-100; e c) org-PIR-100.]

The X-ray diffractograms of the studied clays are shown in Fig. 2, in which the predominant mineralogical constituents kaolinite, illite, and quartz were identified. This result was consistent with the chemical analysis of clays which showed the presence of $\mathrm{Al}_{2} \mathrm{O}_{3}$ and $\mathrm{SiO}_{2}$, the main constituents of the clay minerals identified in the diffractograms. Bragg's law was used to estimate the basal spacing $\mathrm{d}_{001}$ through XRD analyzes, showing that the location of basal spacing $\mathrm{d}_{001}$ did not result in any change $\left(2 \theta \approx 10.5^{\circ}, \mathrm{d} \approx 8.4 \AA\right)$, and not showing any new peaks. A small change was observed at $2 \theta \approx 6.0^{\circ}$, probably due to montmorillonite $[18,19]$, which as a rule favors changes in basal spacing promoted by intercalation of organic cation and are widely used when modified in effluent treatment [37]; part of the organic salt was probably incorporated onto the external surface of the clay $[38,39]$. It should be noted that FTIR analysis confirmed that salt was incorporated in the org-PIR-100, which demonstrated high removal capacity probably due to the electrostatic interactions resulting from the nitrogen present in the salt with the aluminosilicates and iron.

Fig. 3 shows the TG and DTG curves of the clays. The thermograms of the PIR and PIR-100 clays showed two decomposition stages; the first occurred between 25 and

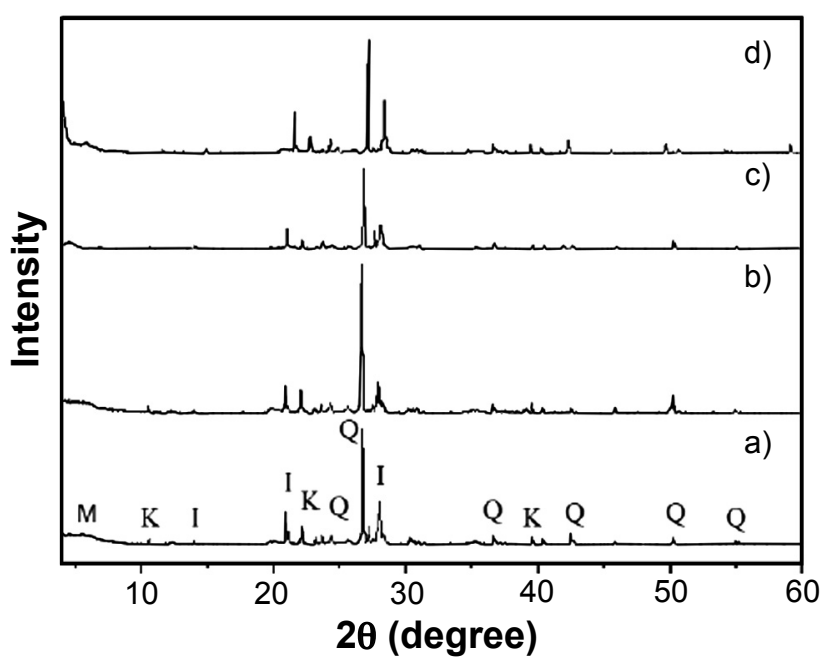

Figure 2: X-ray diffractograms of clays: a) PIR; b) PIR-100; c) org-PIR-100; and d) org-PIR-100 after SMX adsorption. M: montmorillonite; I: illite; K: kaolinite; Q: quartz.

[Figura 2: Difratogramas de raios $X$ das argilas: a) PIR; b) PIR100; c) org-PIR-100; e d) org-PIR-100 após adsorção.]

$170{ }^{\circ} \mathrm{C}$, with the maximum peak identified by the DTG at $90{ }^{\circ} \mathrm{C}$ attributed to the removal of physically adsorbed water, and equivalent to $1.7 \%$ and $1.4 \%$ of mass loss, respectively $[17,40,41]$. The thermal events between 170 and $700{ }^{\circ} \mathrm{C}$ with the maximum peak at $470{ }^{\circ} \mathrm{C}$ and loss of mass of $4.4 \%$ for PIR clay and $3.1 \%$ for PIR-100 clay were attributed to dehydroxylation in the clay layers. Therefore, the total mass loss was $6.1 \%$ and $4.3 \%$, corresponding to 1.85 and $1.29 \mathrm{mg}$, respectively [36, 40, 41]. It was observed that the mass loss for PIR was higher than PIR-100 because the loss was related to water loss and dehydroxylation of the clays, and part of water content was probably eliminated with the heat treatment at $100{ }^{\circ} \mathrm{C}$. The org-PIR-100 thermogram showed decomposition in 3 stages; the first occurred between 25 and $130{ }^{\circ} \mathrm{C}$, with a peak identified by DTG at $70{ }^{\circ} \mathrm{C}$ attributed to the removal of physically adsorbed water, equivalent to $0.4 \%$ of mass loss $[17,34,35]$. The maximum peak at $250{ }^{\circ} \mathrm{C}$ and mass loss of $10.8 \%$ between 170 and $320^{\circ} \mathrm{C}$ were characterized by loss of physically adsorbed surfactant $[36,41]$. The peak at $440{ }^{\circ} \mathrm{C}$ and mass loss of $3.3 \%$ between 320 and $500{ }^{\circ} \mathrm{C}$ were attributed to the evaporation, dehydroxylation in the clay layers and decomposition of intercalated surfactant [33]. Therefore, the total mass loss was $14.5 \%$, corresponding to $4.39 \mathrm{mg}$. In addition, it was noted that the dehydroxylation temperature and the mass loss for org-PIR-100 decreased in comparison to the other clays due to the substitution of water adsorbed in the structure for the surfactant molecules [38, 41].

Table III shows the textural characteristics of the PIR, PIR-100, and org-PIR-100. The modification of the clay with the HDTMA surfactant reduced the specific surface area and the total pore volume because some of the clay pores were blocked by the surfactant molecules which were also incorporated on the outer surface of the clay, which then led to less access to the amount of $\mathrm{N}_{2}$ adsorption $[18,26$, 38]. The increase in the average pore diameter was related 

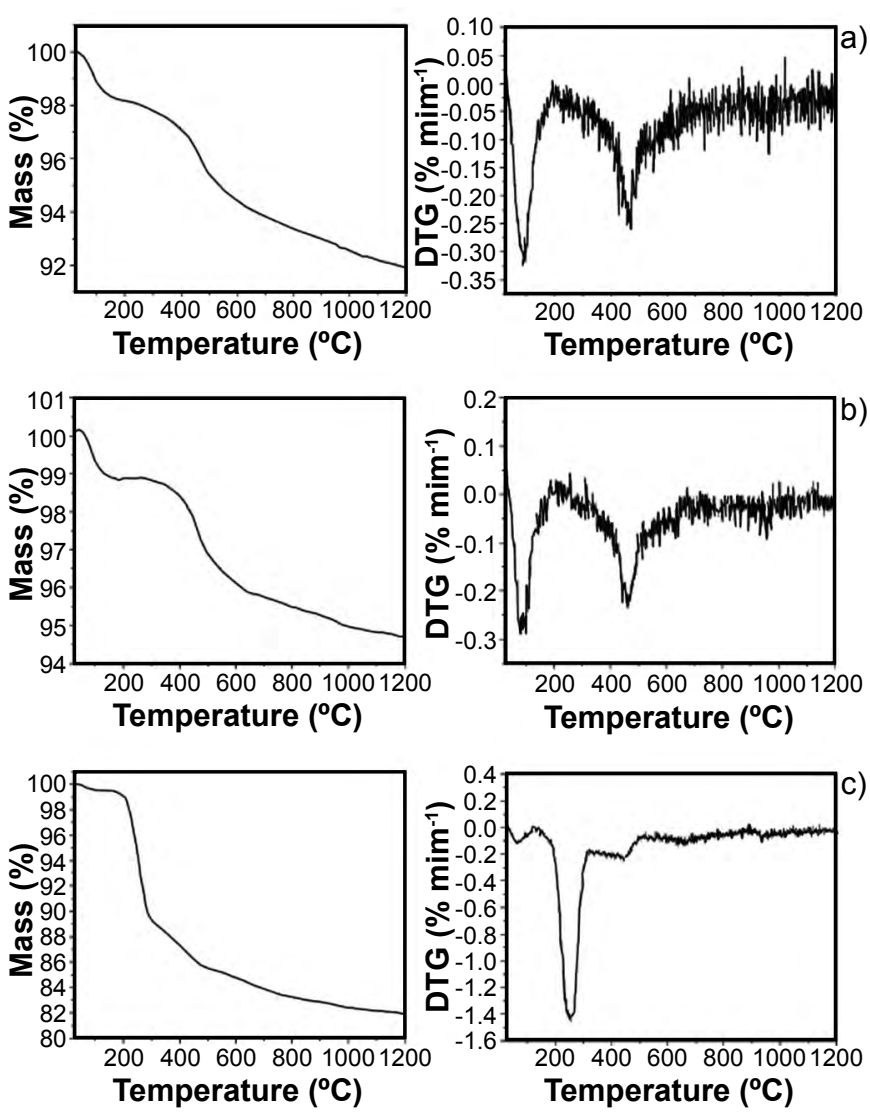

Figure 3: TG and DTG curves of clays: a) PIR; b) PIR-100; and c) org-PIR-100.

[Figura 3: Curvas TG e DTG das argilas: a) PIR; b) PIR-100; e c) org-PIR-100.]

to the surfactant loading because the clay layers were almost completely closed, and the pores were increased by the charged surfactant molecules [33]. The modification of the clay with HDTMA surfactant promoted an alteration on the average pore diameter of the clay (Table III), as the pore diameter was increased by approximately $157 \%$ when the clay was modified with HDTMA [18]. The isotherms of $\mathrm{N}_{2}$ adsorption-desorption of the clays are shown in Fig. 4, with both isotherms of type II according to IUPAC [42] and presenting a wide type $\mathrm{H} 3$ hysteresis characteristic of mesoporous materials $(2<\mathrm{DMP}<50 \mathrm{~nm})$. It should be noted that the amount of $\mathrm{N}_{2}$ adsorbed was lower in org-PIR-100 and the hysteresis loop became very narrow after modifying with HDTMA, indicating that mesopores were blocked

Table III - Textural characteristics of clays.

[Tabela III - Características texturais das argilas.]

\begin{tabular}{cccc}
\hline Clay & $\begin{array}{c}\mathrm{S}_{\mathrm{BET}} \\
\left(\mathrm{m}^{2} \cdot \mathrm{g}^{-1}\right)\end{array}$ & $\begin{array}{c}\mathrm{TPV} \\
\left(\mathrm{cm}^{3} \cdot \mathrm{g}^{-1}\right)\end{array}$ & $\begin{array}{c}\mathrm{MPD} \\
(\mathrm{nm})\end{array}$ \\
\hline PIR & 30.38 & 0.0393 & 5.17 \\
PIR-100 & 30.30 & 0.0398 & 5.25 \\
org-PIR-100 & 2.09 & 0.0071 & 13.51 \\
\hline
\end{tabular}

$S_{B E T}$ - specific surface area; TPV - total pore volume; MPD - mean pore diameter.

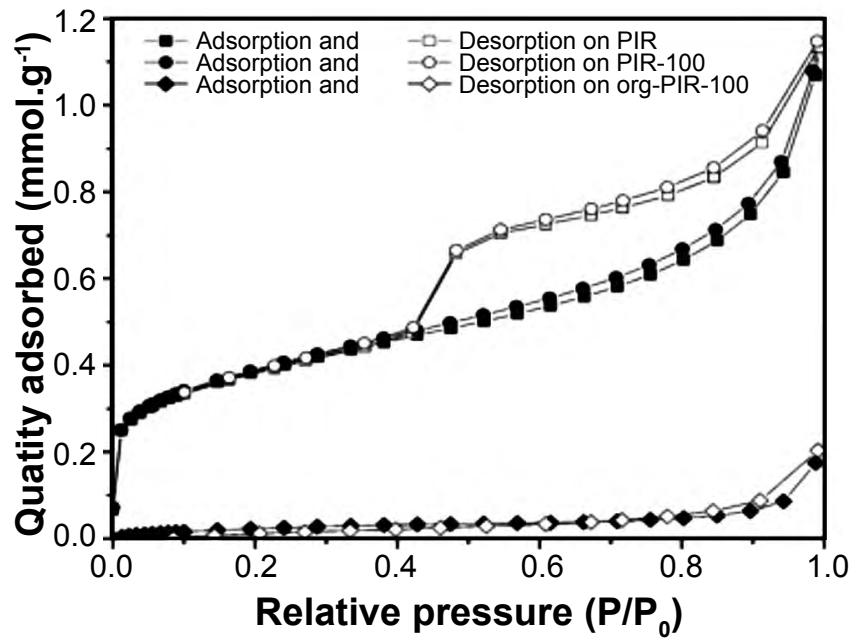

Figure 4: Nitrogen adsorption-desorption isotherms of clays.

[Figura 4: Isotermas de adsorção-dessorção de nitrogênio das argilas.]

during clay modification [18].

The initial $\mathrm{pH}$ is an important factor that can alter the surface charge of the adsorbents, as well as the existing form of SMX $[38,43]$. The point of zero charge, $\mathrm{pH}_{\mathrm{PZC}}$, of an adsorbent is defined as the $\mathrm{pH}$ at which the surface charge becomes zero $[19,26]$. This is an important parameter in the adsorption process, especially when electrostatic forces are involved in the mechanisms [26]. According to Fig. 5a, the $\mathrm{pH}_{\mathrm{PZC}}=6.93$ for org-PIR-100, which means that the molecules do not carry electric charge at this specific $\mathrm{pH}$. The surface of the adsorbent presents positive charge below the $\mathrm{pH}_{\mathrm{PZC}}$, and a negative charge above it $[19,44,45]$. The SMX has two $\mathrm{pKa}$ values. The $\mathrm{pKa} 1=1.6$ corresponds to the protonation of the aniline $\mathrm{N}$, while the $\mathrm{pKa} 2=5.7$ to the deprotonation of the sulfonamide [16]. When $\mathrm{pH}=\mathrm{pKa}$, there is a coexistence of $50 \%$ for neutral species and $50 \%$ for deprotonated species [18]. Thus, SMX is predominantly positively charged if $\mathrm{pH}<\mathrm{pKa} 1\left(\mathrm{SMX}^{+}\right)$, as a neutral species if $\mathrm{pKa} 1<\mathrm{pH}<\mathrm{pKa} 2$ $\left(\mathrm{SMX}^{0}\right)$, and negatively charged if $\mathrm{pH}>\mathrm{pKa} 2\left(\mathrm{SMX}^{-}\right)$[1]. Fig. 5b shows the influence of $\mathrm{pH}$ on SMX adsorption on org-PIR-100. At $\mathrm{pH}=2$, the adsorbent surface was positively charged and the SMX was in the cationic form, $\mathrm{SMX}^{+}$, causing strong electrostatic repulsion with the clay [29, 43]. When $\mathrm{pH}=4$, the adsorbent surface was positively charged and the adsorbate was in its neutral form, $\mathrm{SMX}^{0}$, leading to an increase in the amount of adsorbed SMX as the electrostatic attraction plays a more representative role [43]. At $\mathrm{pH}=6$, the adsorbent was positively charged and the SMX was in its anionic form, SMX, with adsorption occurring by electrostatic and mainly hydrophobic attraction [43]. As the $\mathrm{pH}$ increased from 6 to 8 and 10, there was an increase in ionization and, since SMX and org-PIR-100 were more negatively charged, adsorption decreased due to increasing electrostatic repulsion and may have led to a reduction in hydrophobic interactions with the adsorbent [46].

The kinetic parameters were estimated using the pseudo-first and pseudo-second-order models (Eqs. C and D) and are presented in Table IV. Experimental data 

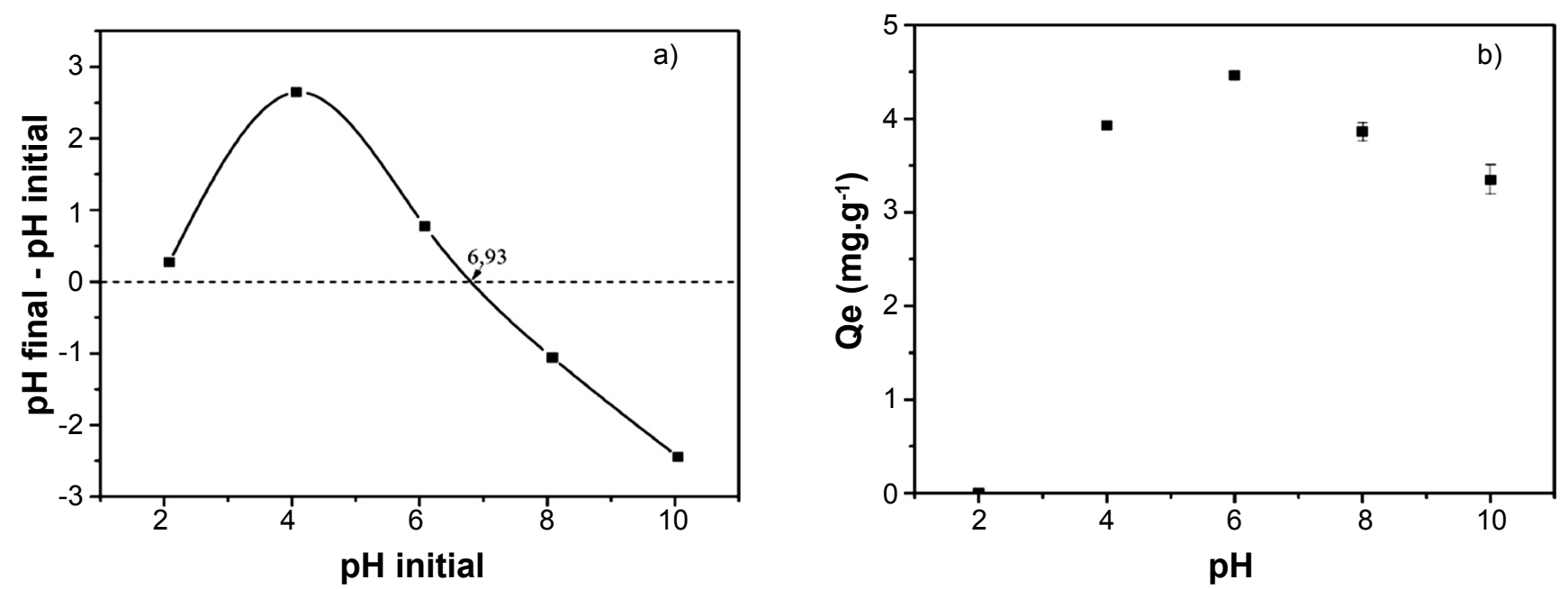

Figure 5: $\mathrm{pH}_{\mathrm{PCZ}}$ (a) and influence of $\mathrm{pH}$ on the SMX adsorption (b) on org-PIR-100 clay.

[Figura 5: $\mathrm{pH}_{P C Z}($ a) e influência do $\mathrm{pH}$ na adsorção do SMX (b) na argila org-PIR-100.]

Table IV - Kinetic parameters of SMX adsorption on org-PIR-100.

[Tabela IV - Parâmetros cinéticos de adsorção do SMX em org-PIR-100.]

\begin{tabular}{cccccc}
\hline Model & $\mathrm{Q}_{\mathrm{e}, \mathrm{exp}}\left(\mathrm{mg} \cdot \mathrm{g}^{-1}\right)$ & $\mathrm{Q}_{\mathrm{e}, \mathrm{calc}}\left(\mathrm{mg} \cdot \mathrm{g}^{-1}\right)$ & $\mathrm{k}_{1}\left(\mathrm{~min}^{-1}\right)$ & $\mathrm{k}_{2}\left(\mathrm{~g} \cdot \mathrm{mg}^{-1} \cdot \mathrm{min}^{-1}\right)$ & $\mathrm{r}^{2}$ \\
\hline Pseudo-first order & $4.48 \pm 0.01$ & $4.32 \pm 0.07$ & $0.46 \pm 0.05$ & - & 0.884 \\
Pseudo-second order & $4.48 \pm 0.01$ & $4.50 \pm 0.02$ & - & $0.181 \pm 0.007$ & 0.994 \\
\hline
\end{tabular}

are generally better described by the second-order model, which presupposes adsorption involving electron donation or exchange between the adsorbate and the adsorbent (chemical adsorption) [13, 46, 47]. From Fig. 6, it can be observed that the SMX adsorption was fast (observed from 2 $\mathrm{min}$ ), reaching the equilibrium in about $100 \mathrm{~min}$ of contact, and presenting $90 \%$ removal efficiency. The Langmuir and Freundlich isotherms, represented by Eqs. D and F, were used to describe equilibrium at $15,25,35$ and $45^{\circ} \mathrm{C}$. The estimated parameters are presented in Table V. The presented $r^{2}$ values suggested that the experimental data were better fit using the Langmuir isotherm, whose model is based

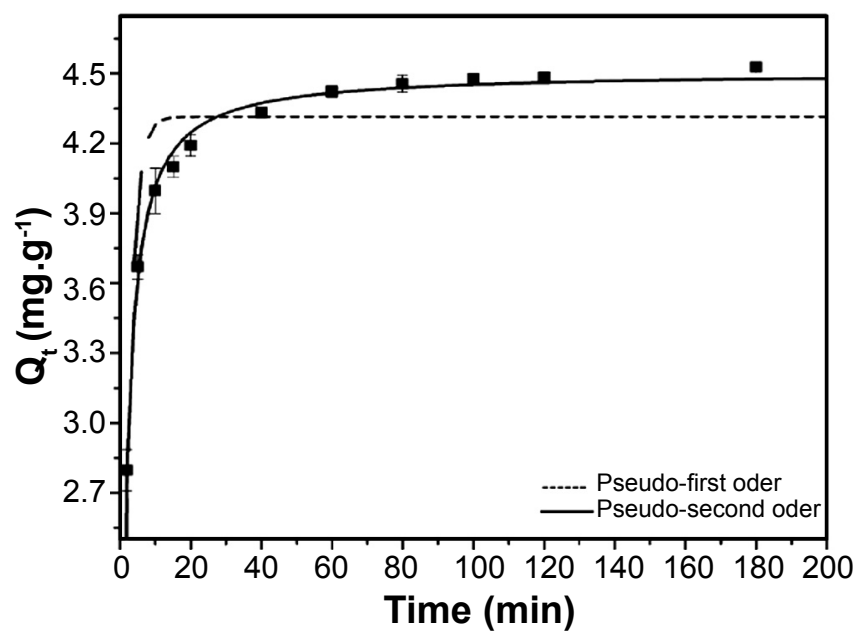

Figure 6: Kinetic of adsorption of SMX on org-PIR-100.

[Figura 6: Cinética de adsorção do SMX em org-PIR-100.] on the assumption of localized adsorption in a monolayer (chemical adsorption), where all the adsorption sites are identical and that the adsorption heat is independent of the amount of adsorbed material [48, 49]. Moreover, it can be stated that the adsorption was favorable, because the process presented the Langmuir separation factor $\left(\mathrm{R}_{\mathrm{L}}\right)$ between 0 and $1[43,50]$. It is further noted from Table $\mathrm{V}$ that the difference between the maximum adsorption capacities at 15 and $25^{\circ} \mathrm{C}$ was not significant, thus justifying the use of the material at room temperature $\left(25^{\circ} \mathrm{C}\right)$ in order to avoid a step for cooling the solution containing SMX.

Fig. 7 shows the equilibrium results of the SMX adsorbed in org-PIR-100 fitted to the Langmuir model. The adsorption isotherms obtained were favorable because a relatively high amount of adsorbate in the solids can be obtained even at low levels of fluid equilibrium concentration [51]. The temperature slightly influenced the adsorption process, as observed by the $\mathrm{Q}_{\max }$ value (Table $\mathrm{V}$ ) and by the low value of $\Delta \mathrm{H}<0$. Due to the low $\Delta \mathrm{H}$ value, the temperature may favor the adsorption depending on the occupation conditions of the active sites; for example, the $\mathrm{Q}_{\mathrm{e}}$ quantity was higher at $35^{\circ} \mathrm{C}$ and $\mathrm{C}_{\mathrm{e}}$ concentrations below $5 \mathrm{mg} \cdot \mathrm{L}^{-1}$ than at the temperatures of 15 and $25^{\circ} \mathrm{C}$, with a decrease in the adsorbed amount to concentrations above $5 \mathrm{mg} . \mathrm{L}^{-1}$; this was probably due to the exothermic process and due to the saturation of the active sites. The values of the thermodynamic variables studied in the range of 15 to $45^{\circ} \mathrm{C}$ and using the Eqs. $\mathrm{H}$ to $\mathrm{J}$ and conditions $\mathrm{C}_{\mathrm{o}}=50 \mathrm{mg} \cdot \mathrm{L}^{-1}, \mathrm{~V}=50 \mathrm{~mL}$ and $\mathrm{m}=100 \mathrm{mg}$ are shown in Table VI. Using Eq. I, it was possible to calculate the parameters $\Delta \mathrm{H}^{\circ}=-10.50 \mathrm{~kJ} \cdot \mathrm{mol}^{-1}$ and $\Delta \mathrm{S}^{\circ}=-0.029 \mathrm{~kJ} \cdot \mathrm{mol}^{-1} . \mathrm{K}^{-1}$; similar 
Table V - Equilibrium parameters for the adsorption of SMX in org-PIR-100.

[Tabela V - Parâmetros de equilíbrio para a adsorção do SMX em org-PIR-100.]

\begin{tabular}{cccccccc}
\hline $\begin{array}{c}\text { Temperature } \\
\left({ }^{\circ} \mathrm{C}\right)\end{array}$ & $\mathrm{Q}_{\max }\left(\mathrm{mg} \cdot \mathrm{g}^{-1}\right)$ & $\mathrm{b}\left(\mathrm{L} \cdot \mathrm{mg}^{-1}\right)$ & $\mathrm{R}_{\mathrm{L}}$ & $\mathrm{r}^{2}$ & $\mathrm{~K}_{\mathrm{f}}\left(\left[\mathrm{L} \cdot \mathrm{g}^{-1}\right]^{1 / \mathrm{n}}\right)$ & $1 / \mathrm{n}$ & $\mathrm{r}^{2}$ \\
\hline 15 & $27.4 \pm 1.7$ & $0.29 \pm 0.05$ & 0.055 & 0.983 & $7.3 \pm 1.3$ & $0.43 \pm 0.08$ & 0.903 \\
25 & $27.3 \pm 1.3$ & $0.35 \pm 0.05$ & 0.045 & 0.990 & $7.6 \pm 0.8$ & $0.45 \pm 0.05$ & 0.963 \\
35 & $23.2 \pm 1.7$ & $0.58 \pm 0.17$ & 0.028 & 0.963 & $8.9 \pm 0.7$ & $0.34 \pm 0.04$ & 0.971 \\
45 & $23.4 \pm 1.6$ & $0.33 \pm 0.07$ & 0.048 & 0.975 & $7.0 \pm 1.0$ & $0.38 \pm 0.06$ & 0.928 \\
\hline
\end{tabular}

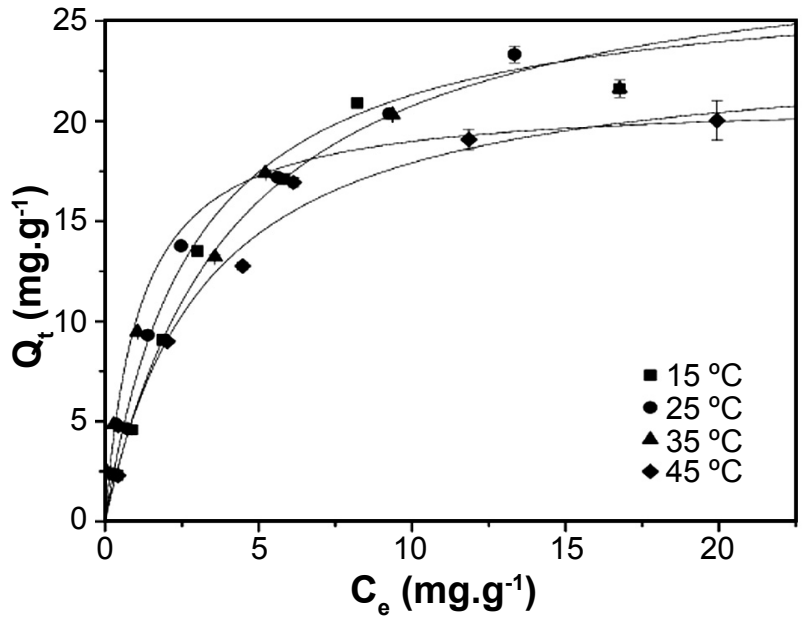

Figure 7: Isotherms of the SMX adsorption in org-PIR-100 adjusted by the Langmuir model.

[Figura 7: Isotermas de equilibrio de adsorção do SMX em orgPIR-100 ajustadas pelo modelo de Langmuir.]

Table VI - Thermodynamic variables for the SMX adsorption in org-PIR-100 $\left(\mathrm{C}_{\mathrm{o}}=50 \mathrm{mg} \cdot \mathrm{L}^{-1}, \mathrm{~V}=50 \mathrm{~mL}, \mathrm{~m}=0.1 \mathrm{~g}\right)$.

[Tabela VI - Variáveis termodinâmicas para adsorção do SMX em org-PIR-100 ( $\left.\left.C_{o}=50 \mathrm{mg} . \mathrm{L}^{-1}, V=50 \mathrm{~mL}, \mathrm{~m}=0,1 \mathrm{~g}\right).\right]$

\begin{tabular}{ccc}
\hline Temperature $(\mathrm{K})$ & $\Delta \mathrm{G}^{\circ}\left(\mathrm{kJ} \cdot \mathrm{mol}^{-1}\right)$ & $\mathrm{K}_{\mathrm{C}}(\mathrm{L} / \mathrm{g})$ \\
\hline 288.15 & -2.287 & 2.546 \\
298.15 & -2.002 & 2.200 \\
308.15 & -1.717 & 2.170 \\
318.15 & -1.431 & 1.610 \\
\hline
\end{tabular}

values were observed in studies in the literature [29, 43, 50]. The results suggested that the adsorption was an exothermic process $\left(\Delta \mathrm{H}^{\circ}<0\right)$ and decreased the randomness at the solidliquid interface $\left(\Delta \mathrm{S}^{\circ}<0\right)$. The values of $\Delta \mathrm{G}^{\circ}<0$ indicated that the adsorption process was viable and spontaneous, decreasing with the increase in temperature. This last variable together with the $\mathrm{R}_{\mathrm{L}}$ values confirmed that the process was favorable $[29,43]$.

\section{CONCLUSIONS}

In this study, the adsorption capacity of sulfamethoxazole (SMX) was studied using organophilic clay (org-PIR-100) obtained by modification with HDTMA cationic surfactant of a Pirangi clay from the State of Sergipe/Brazil. The XRD analysis identified crystalline modification in
$2 \theta \approx 6.0^{\circ}$ due to montmorillonite, evidencing that the organophilization treatment process enables an increase in the adsorption capacity of the clay, mainly in clays that have montmorillonite in their composition, even in small amounts. The analyzes by XRF, FTIR, XRD, TG/DTG and BET showed incorporation of the organic cation from HDTMA in the clay. The SMX adsorption in org-PIR-100 was $\mathrm{pH}$-dependent through electrostatic interactions, mainly hydrophobic, and adsorption reached equilibrium in about 100 min with $90 \%$ removal according to the determined kinetic and equilibrium parameters and was controlled by the second-order kinetics and Langmuir isotherm, with a maximum adsorption capacity of $27.4 \mathrm{mg} \cdot \mathrm{g}^{-1}$ at $15^{\circ} \mathrm{C}$. The thermodynamic studies showed that the temperature was slightly influential in the removal of the SMX adsorption process using org-PIR-100, and there was an increase in the adsorption capacity at the lower temperatures used due to the slightly exothermic process. In summary, the results showed that Pirangi clay can be used in water treatment plant filters, for example, as an alternative material for SMX removal.

\section{ACKNOWLEDGMENTS}

The authors would like to thank the Federal University of Sergipe (UFS), LQI, the State University of Maringá (UEM), CAPES, and FAPITEC (Sergipe) for financial support.

\section{REFERENCES}

[1] S. Willach, H.V. Lutze, K. Eckey, K. Löppenberg, M. Lüling, J. Terhalle, J.B. Wolbert, M.A. Jochmann, U. Karst, T.C. Schmidt, Water Res. 122 (2017) 280.

[2] L. Chu, J. Wang, Phys. Chem. 130 (2017) 391.

[3] V. Lozano-Morales, I. Gardi, S. Nir, T. Undabeytia, J. Clean. Prod. 190 (2018) 703.

[4] J. Rivera-Utrilla, M. Sánchez-Polo, M.Á. Ferro-García, G. Prados-Joya, R. Ocampo-Pérez, Chemosphere 93 (2013) 1268.

[5] K.L. Chen, L.C. Liu, W.R. Chen, Environ. Pollut. 231 (2017) 1163.

[6] M. Kobayashi, S. Kurosu, R. Yamaguchi, Y. Kawase, J. Environ. Manage. 200 (2017) 88.

[7] L. Patrolecco, J. Rauseo, N. Ademollo, P. Grenni, M. Cardoni, C. Levantesi, M.L. Luprano, A.B. Caracciolo, Sci. Total Environ. 640 (2018) 1438. 
[8] K. Styszko, K. Nosek, M. Motak, K. Bester, C. R. Chim. 18 (2015) 1134.

[9] A.V. Dordio, S. Miranda, J.P. Prates Ramalho, A.J.P. Carvalho, J. Hazard. Mater. 323 (2017) 575.

[10] V. Arya, L. Philip, Microporous Mesoporous Mater. 232 (2016) 273.

[11] S. Bentahar, A. Dbik, M. El Khomri, N. El Messaoudi, A. Lacherai, Groundw. Sustain. Dev. 6 (2018) 255.

[12] Y. Wu, Y. Si, D. Zhou, J. Gao, Chemosphere 119 (2015) 690.

[13] Y. Park, G.A. Ayoko, R. Kurdi, E. Horváth, J. Kristóf, R.L. Frost, J. Colloid Interface Sci. 406 (2013) 196.

[14] A.C.S. Alcântara, M.S.S. Beltrão, H.A. Oliveira, I.F. Gimenez, L.S. Barreto, Appl. Clay Sci. 39 (2008) 160.

[15] J.R. Goes, T.F. Azevedo, T.X.C. Dutra, V.B. Santos, J.B. Severo Junior, L.S. Barreto, Cerâmica 60, 354 (2014) 211.

[16] C.P. Santos, H.A. Oliveira, R.M.P.B. Oliveira, Z.S. Macedo, Cerâmica 62, 362 (2016) 147.

[17] H.A. Oliveira, D.C. Silva, R.M.P.B. Oliveira, C.P. Santos, E. de Jesus, Z.S. Macedo, Appl. Clay Sci. 161 (2018) 211.

[18] J.I. Martinez-Costa, R. Leyva-Ramos, Colloids Surf. A 520 (2017) 676.

[19] T.S. Anirudhan, M. Ramachandran, Process Saf. Environ. Prot. 95 (2015) 215.

[20] R.C. dos Santos, T.R. da Silva, G. de A. Neves, R.S. de Macedo, R.R. Menezes, L.N. de L. Santana, Cerâmica 63, 367 (2017) 361.

[21] W.P. Gonçalves, V.J. Silva, J. Gomes, R.R. Menezes, G.A. Neves, H.C. Ferreira, L.N.L. Santana, Cerâmica 60, 355 (2014) 316.

[22] J.C.T. Rezende, V.H.S. Ramos, H.A. Oliveira, R.M.P.B. Oliveira, E. Jesus, Mater. Sci. Forum 912 (2018) 1.

[23] ASTM D 2974-87, "Standard test methods for moisture, ash, and organic matter of peat and other organic soils", ASTM (1993).

[24] S. Mahmoudi, A. Bennour, E. Srasra, F. Zargouni, Appl. Clay Sci. 135 (2017) 215.

[25] ASTM C837-81, "Standard test method for methylene blue index of clay", ASTM (2014).

[26] I. Ltifi, F. Ayari, D.B.H. Chehimi, M.T. Ayadi, Appl. Water Sci. 8 (2018) 1.

[27] A.F. Neves, M.H. de Paula, P.H.R. dos Anjos, J.L. Bernardo (Orgs.), Estud. interdisc. ciên. amb. territ. mov. soc., Blucher (2016) 31.

[28] S.I. Rathnayake, Y. Xi, R.L. Frost, G.A. Ayoko, J. Colloid Interface Sci. 470 (2016) 183.

[29] J. Wang, M. Gao, F. Ding, T. Shen, Colloids Surf. A 546 (2018) 143.
[30] M.M. Saidian, L.J. Godinez, M. Prasad, J. Nat. Gas Sci. Eng. 33 (2016) 1095.

[31] M.N. Ciotta, C. Bayer, S. Mara, V. Fontoura, P.R. Ernani, J.A., Ciên. Rural 33 (2003) 1161.

[32] M.G. Silva-Valenzuela, M.M. Chambi-Peralta, I.J. Sayeg, F.M. de Souza Carvalho, S.H. Wang, F.R. ValenzuelaDíaz, Appl. Clay Sci. 155 (2018) 111.

[33] M.E. Parolo, G.R. Pettinari, T.B. Musso, M.P. SánchezIzquierdo, L.G. Fernández, Appl. Surf. Sci. 320 (2014) 356. [34] D. Hernández, L. Lazo, L. Valdés, L.C. de Ménorval, Z. Rozynek, A. Rivera, Appl. Clay Sci. 161 (2018) 395.

[35] F. Kooli, L. Yan, S.X. Tan, J. Zheng, J. Therm. Anal. Calorim. 115 (2014) 1465.

[36] K. Taleb, I. Pillin, Y. Grohens, S. Saidi-Besbes, Appl. Clay Sci. 161 (2018) 48.

[37] D.L. Guerra, H.C.P. Oliveira, P.C.C. da Costa, R.R. Viana, C. Airoldi, Catena 82 (2010) 35.

[38] S. Liu, P. Wu, L. Yu, L. Li, B. Gong, N. Zhu, Z. Dang, C. Yang, Appl. Clay Sci. 137 (2017) 160.

[39] K. Sun, Y. Shi, H. Chen, X. Wang, Z. Li, J. Hazard. Mater. 323 (2017) 567.

[40] P.M. Naranjo, J. Molina, E. Ling, E.M. Farfán, Quim. Nova 38 (2015) 166.

[41] Z.M. Wang, H. Ooga, T. Hirotsu, W.L. Wang, Q.Y. Wu, H.Y. Hu, Appl. Clay Sci. 104 (2015) 81.

[42] S.K.S.W. Sing, D.H. Everett, R.A.W. Haul, L. Moscou, R.A. Pierotti, J. Rouquérol, T. Siemieniewska, Pure Appl. Chem. 57 (1985) 603.

[43] L. Lu, M. Gao, Z. Gu, S. Yang, Y. Liu, J. Environ. Sci. 26 (2014) 2535.

[44] D. Avisar, O. Primor, I. Gozlan, H. Mamane, Water Air Soil Pollut. 209 (2010) 439.

[45] M. Pashai Gatabi, H. Milani Moghaddam, M. Ghorbani, J. Mol. Liq. 216 (2016) 117.

[46] F. Wang, W. Sun, W. Pan, N. Xu, Chem. Eng. J. 274 (2015) 17.

[47] X. Zhang, W. Guo, H.H. Ngo, H. Wen, N. Li, W. Wu, J. Environ. Manage. 172 (2016) 193.

[48] E. Çalişkan Salihi, M. Mahramanlioğlu, Appl. Clay Sci. 101 (2014) 38.

[49] T. Thiebault, R. Guégan, M. Boussafir, J. Colloid Interface Sci. 453 (2015) 1.

[50] T. De Oliveira, R. Guégan, T. Thiebault, C. Le Milbeau, F. Muller, V. Teixeira, M. Giovanela, M. Boussafir, J. Hazard. Mater. 323 (2017) 558.

[51] M.W.L. McCabe, J.C. Smith, P. Harriott, Unit operations of chemical engineering, $7^{\text {th }}$ ed., McGraw-Hill, New York (2014) 1140.

(Rec. 13/04/2019, Rev. 25/05/2019, 21/06/2019, Ac. $28 / 06 / 2019)$ 